\title{
Conformational Equilibria in Formic Acid and the Adduct of Formic Acid and Hexafluoroacetone, $\mathrm{HCO}_{2} \mathrm{C}\left(\mathrm{CF}_{3}\right)_{2} \mathrm{OH}$
}

\author{
Diwakar M. Pawar, Dalephine Cain-Davis, and Eric A. Noe* \\ Contribution from the Department of Chemistry, Jackson State University, P. O. Box No 17910, \\ 1400 J. R. Lynch Street, Jackson, MS 39217 -0510. ean12001@yahoo.com.
}

Table of Contents

No.

1. Figure S1 . Low - temperature ${ }^{1} \mathrm{H}$ NMR spectra of a mixture of formic acid and acetic acid in a ratio of $1: 1$ by volume in a 3:1:1 mixture of $\mathrm{CHClF}_{2}, \mathrm{CHCl}_{2} \mathrm{~F}$, and $\left(\mathrm{CH}_{3}\right)_{2} \mathrm{O}$ containing a small amount of acetic anhydride (Composite spectrum, 1 page).

2. Figures S2 - S19. Low temperature ${ }^{1}$ H NMR spectra of $2 \%$ formic acid $+3 \%$ hexafluoroacetone in 3:1 dimethyl ether / dichloromethane solvent mixture, internal reference TMS added. Full and expanded versions of spectra for eight temperatures. The expanded spectra show peak assignments. (16 pages).

3. Figures S20 - S24. Low temperature ${ }^{13} \mathrm{C}$ NMR spectra of 2\% formic acid + 3\% hexafluoroacetone in 3:1 dimethyl ether / dichloromethane solvent mixture, internal reference TMS added. Full spectra for four temperatures (4 pages) and expanded composite spectra ( 1 page) of the carbonyl region for these temperatures is also provided. 
Figure S1. Low - temperature ${ }^{1} \mathrm{H}$ NMR spectra of a mixture of formic acid and acetic acid in a ratio of 1:1 by volume in a 3:1:1 mixture of $\mathrm{CHClF}_{2}$, $\mathrm{CHCl}_{2} \mathrm{~F}$, and $\left(\mathrm{CH}_{3}\right)_{2} \mathrm{O}$ containing a small amount of acetic anhydride




Figure S2. Low - temperature ${ }^{1} \mathrm{H}$ NMR spectra of $2 \%$ formic acid and 3\% hexafluoroacetone in 1:3 mixture of $\mathrm{CD}_{2} \mathrm{Cl}_{2}$ and $\left(\mathrm{CH}_{3}\right)_{2} \mathrm{O}$.

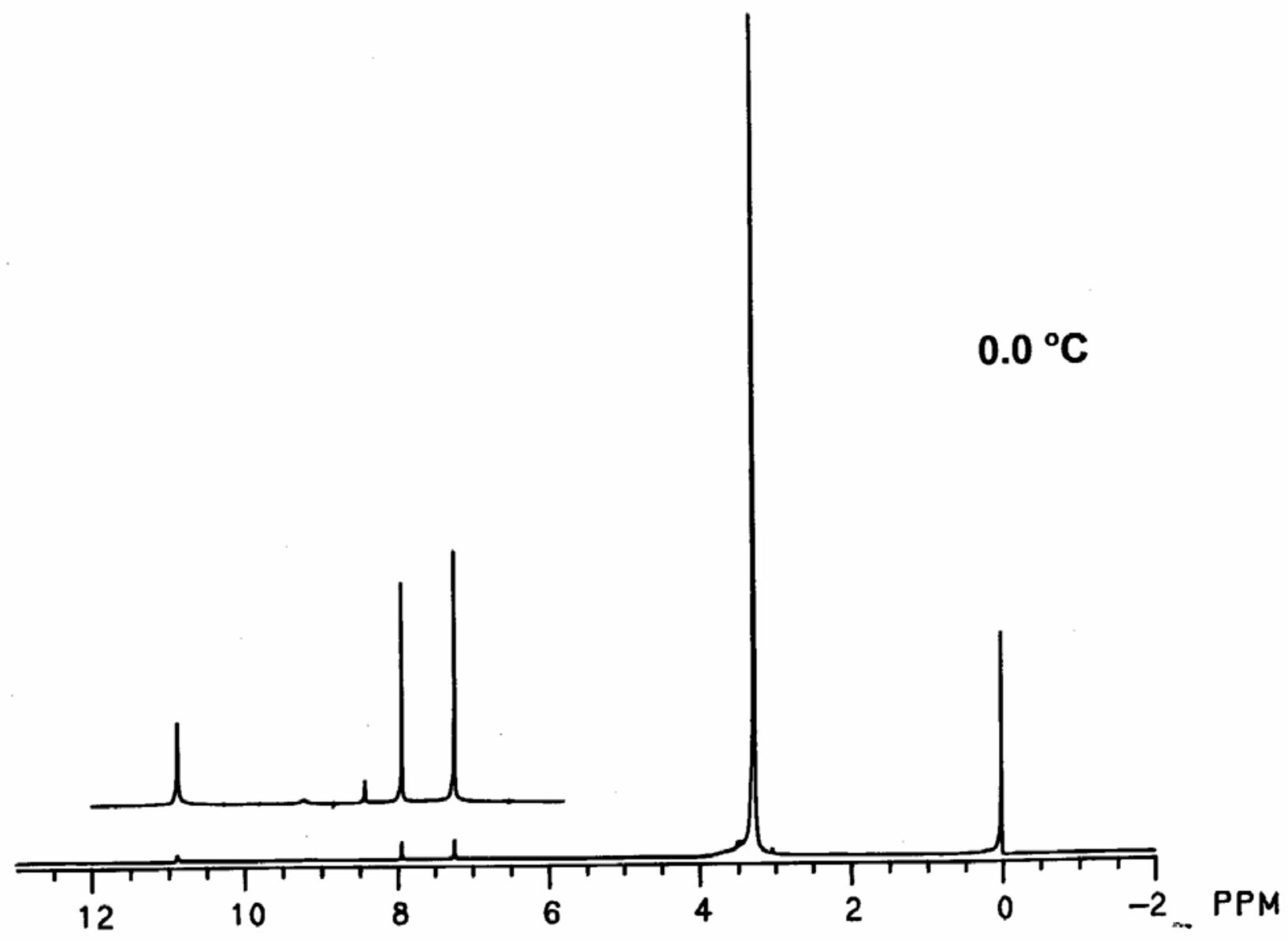


Figure S3 Low - temperature ${ }^{1} \mathrm{H}$ NMR spectra of $2 \%$ formic acid and 3\% hexafluoroacetone in 1:3 mixture of $\mathrm{CD}_{2} \mathrm{Cl}_{2}$ and $\left(\mathrm{CH}_{3}\right)_{2} \mathrm{O}$

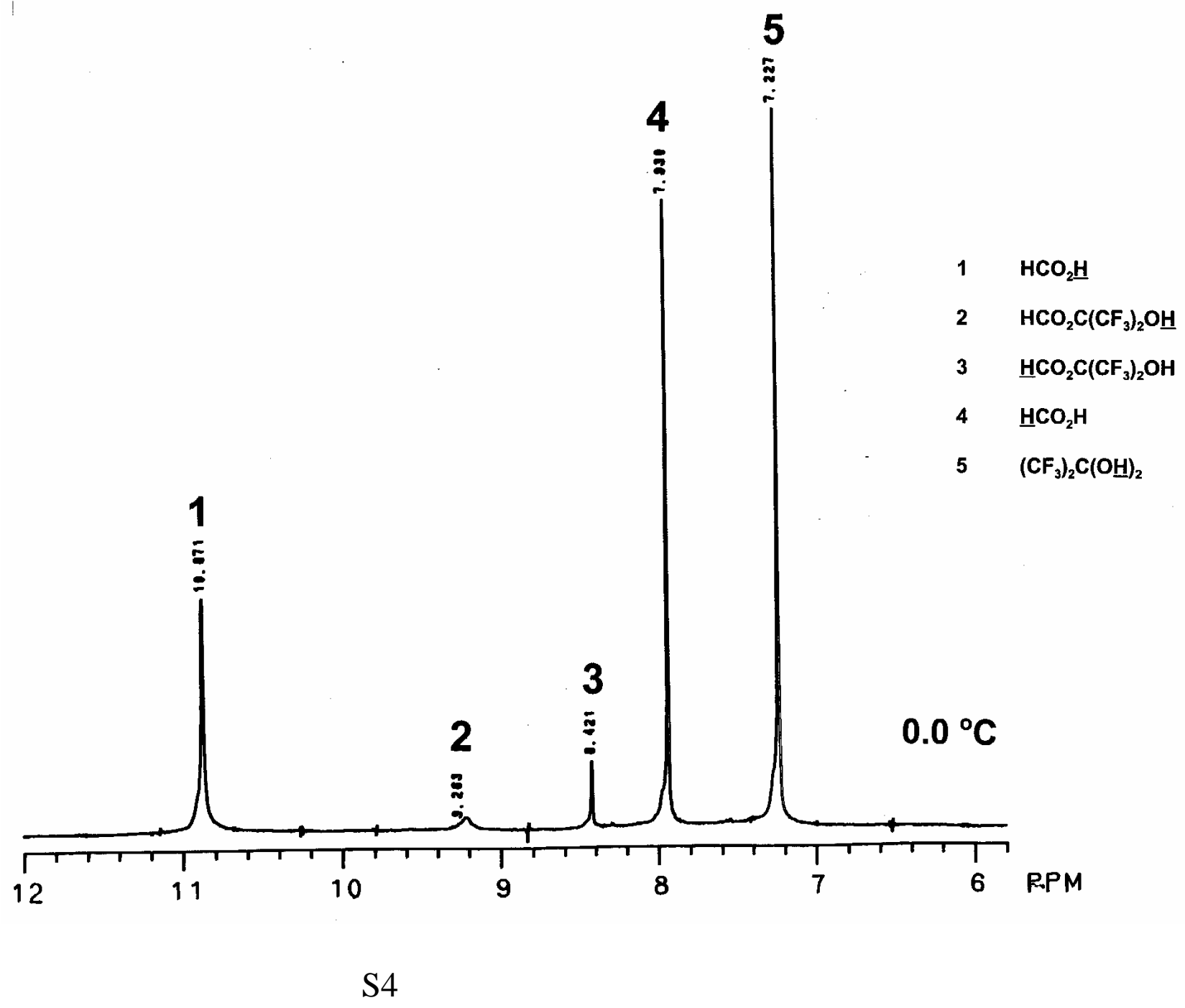


Figure S4. Low - temperature ${ }^{1} \mathrm{H}$ NMR spectra of $2 \%$ formic acid and $3 \%$ hexafluoroacetone in 1:3 mixture of $\mathrm{CD}_{2} \mathrm{Cl}_{2}$ and $\left(\mathrm{CH}_{3}\right)_{2} \mathrm{O}$.

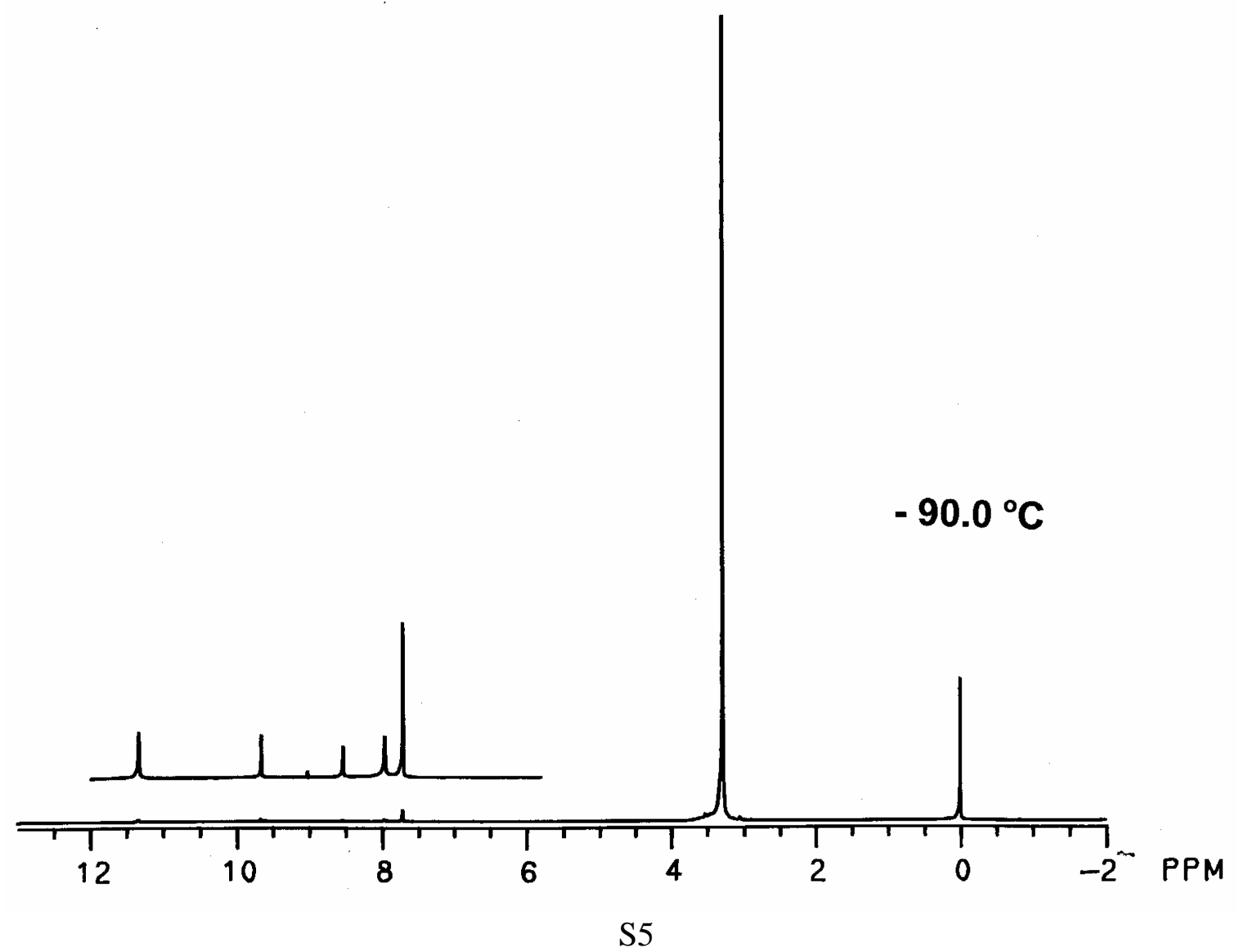


Figure S5. Low - temperature ${ }^{1} \mathrm{H}$ NMR spectra of $2 \%$ formic acid and $3 \%$ hexafluoroacetone in 1:3 mixture of $\mathrm{CD}_{2} \mathrm{Cl}_{2}$ and $\left(\mathrm{CH}_{3}\right)_{2} \mathrm{O}$.

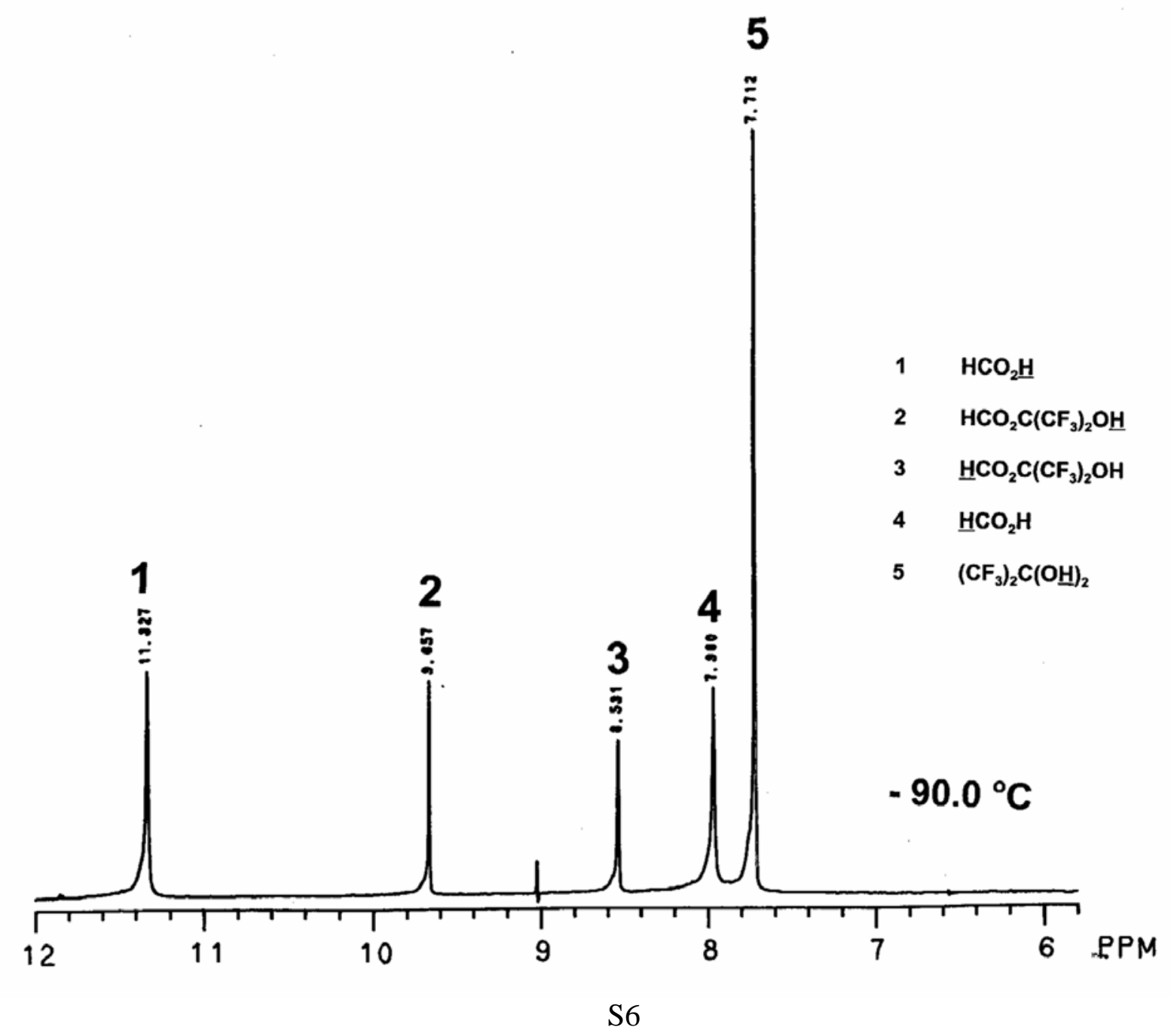


Figure S6. Low - temperature ${ }^{1} \mathrm{H}$ NMR spectra of $2 \%$ formic acid and $3 \%$ hexafluoroacetone in $1: 3$ mixture of $\mathrm{CD}_{2} \mathrm{Cl}_{2}$ and $\left(\mathrm{CH}_{3}\right)_{2} \mathrm{O}$.

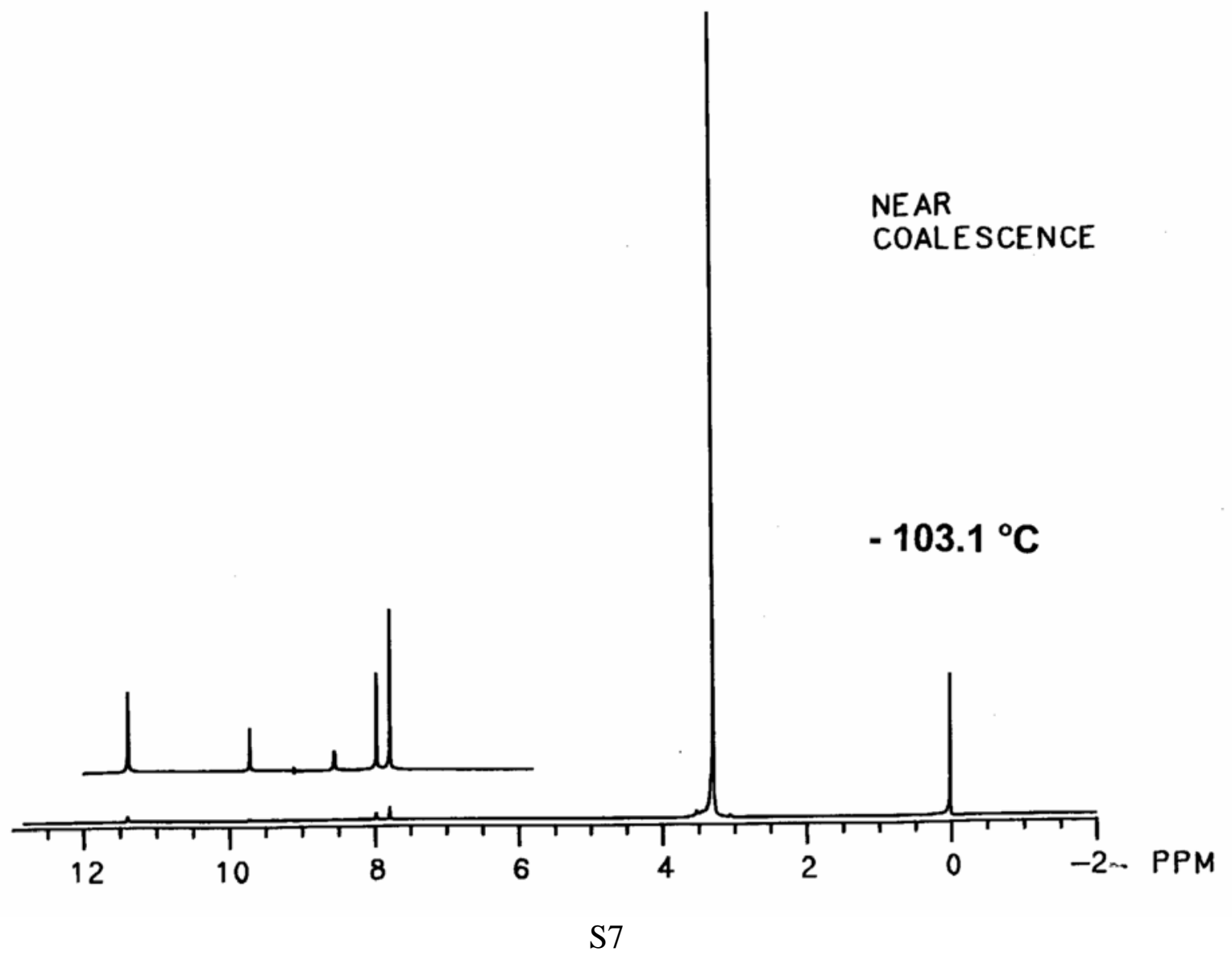


Figure S7. Low - temperature ${ }^{1} \mathrm{H}$ NMR spectra of $2 \%$ formic acid and $3 \%$ hexafluoroacetone in $1: 3$ mixture of $\mathrm{CD}_{2} \mathrm{Cl}_{2}$ and $\left(\mathrm{CH}_{3}\right)_{2} \mathrm{O}$.

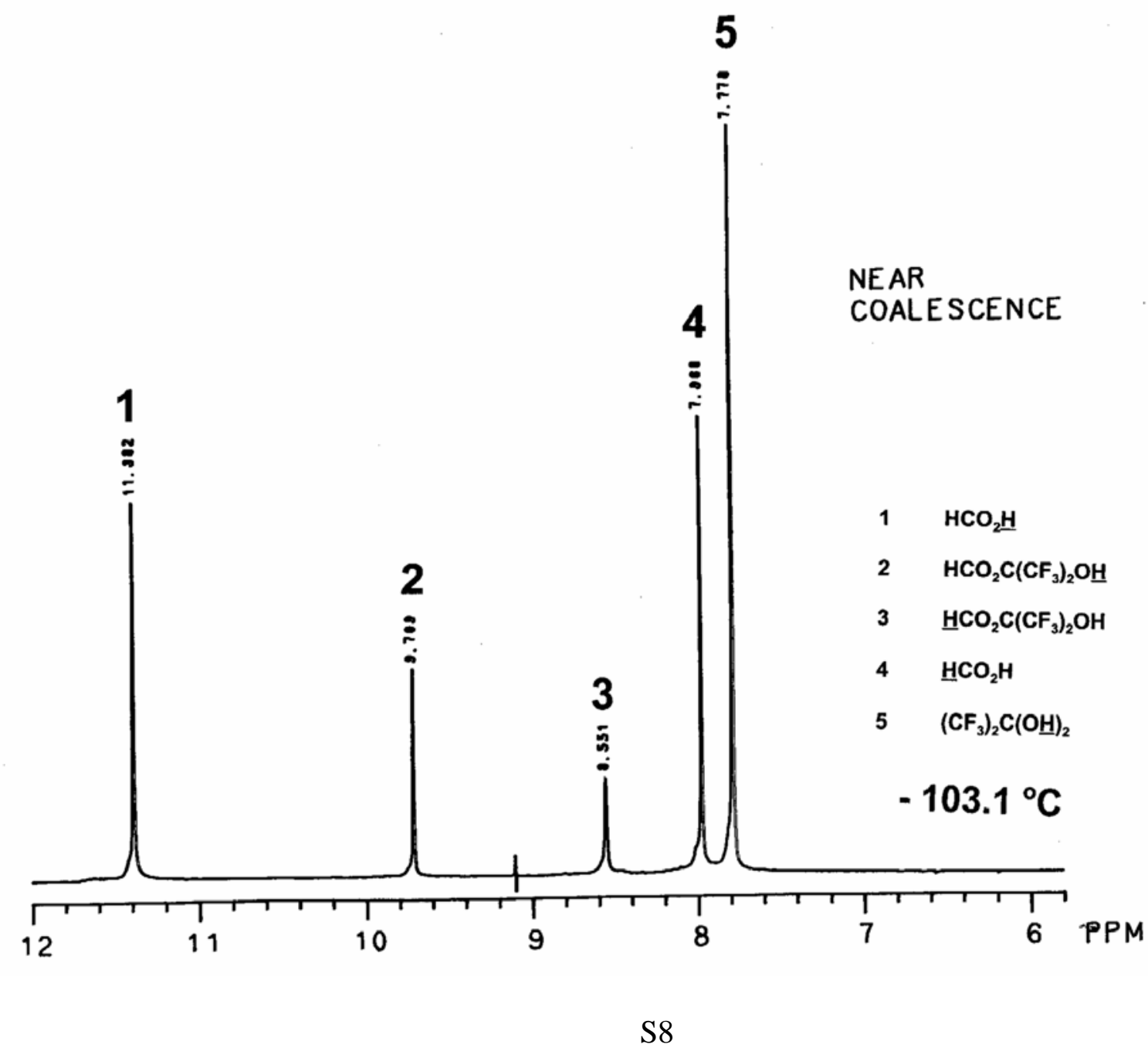


Figure 8. Low - temperature ${ }^{1} \mathrm{H}$ NMR spectra of $2 \%$ formic acid and $3 \%$ hexafluoroacetone in 1:3 mixture of $\mathrm{CD}_{2} \mathrm{Cl}_{2}$ and $\left(\mathrm{CH}_{3}\right)_{2} \mathrm{O}$.

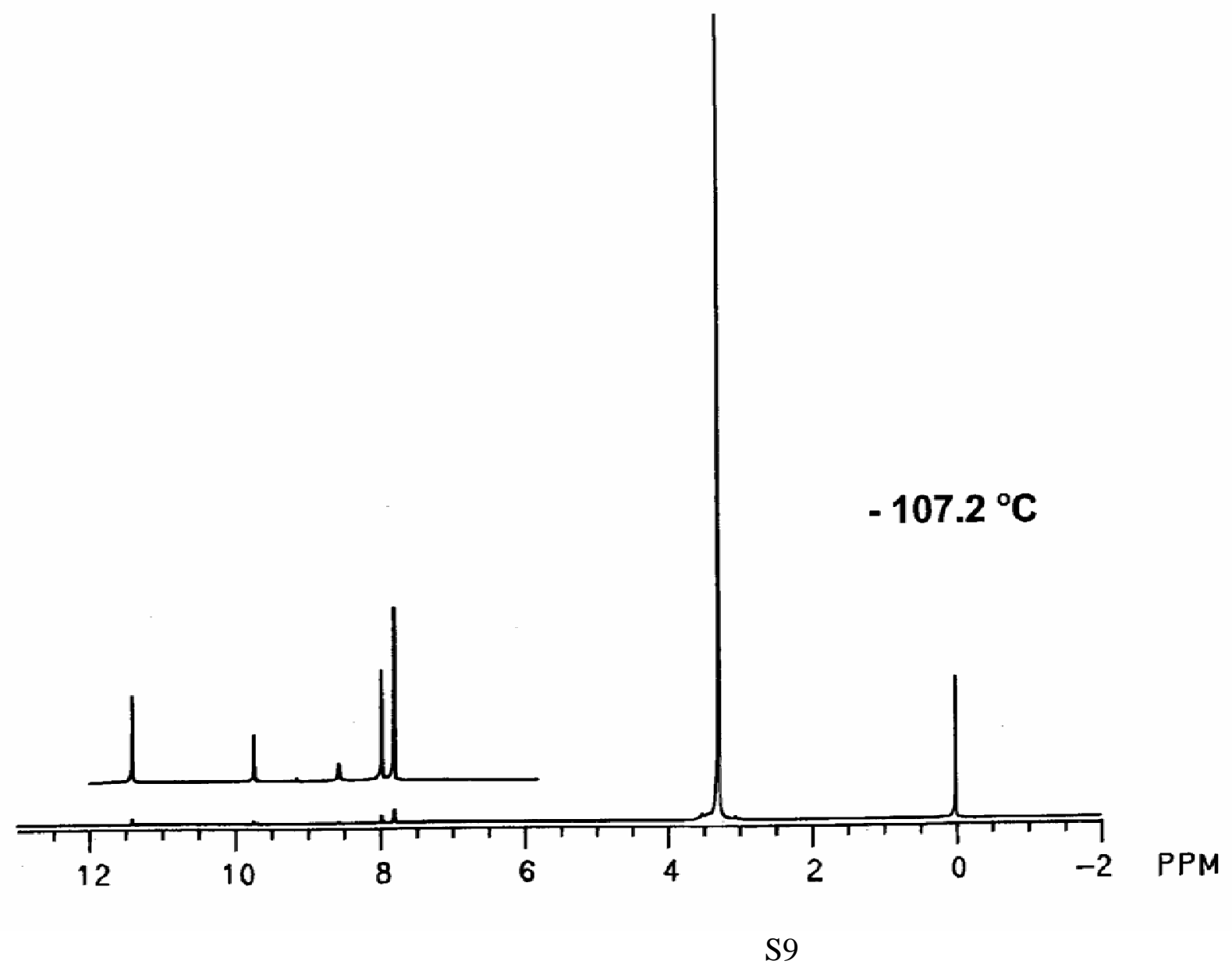


Figure S9. Low - temperature ${ }^{1} \mathrm{H}$ NMR spectra of $2 \%$ formic acid and $3 \%$ hexafluoroacetone in $1: 3$ mixture of $\mathrm{CD}_{2} \mathrm{Cl}_{2}$ and $\left(\mathrm{CH}_{3}\right)_{2} \mathrm{O}$.

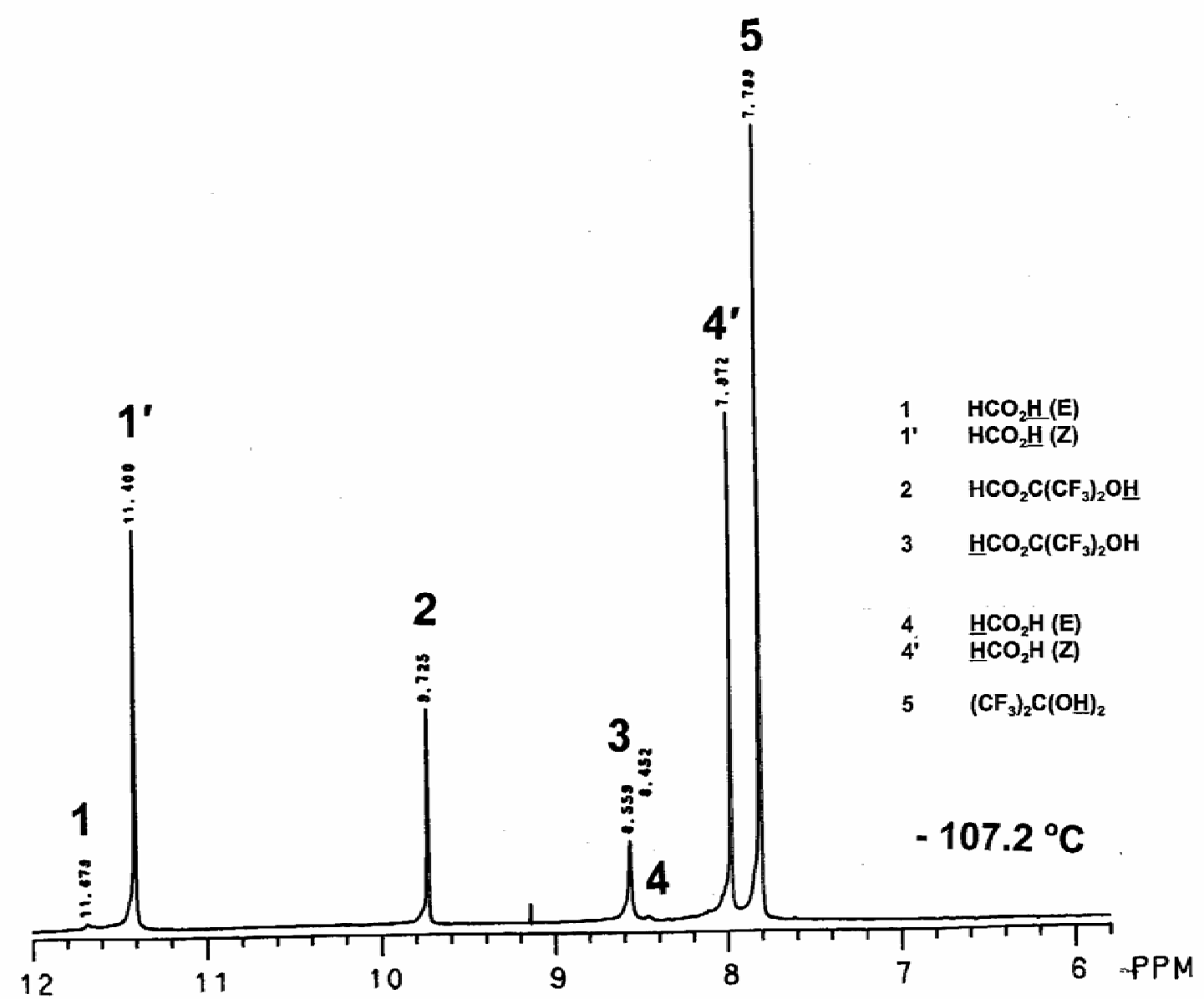


Figure S10. Low - temperature ${ }^{1} \mathrm{H}$ NMR spectra of $2 \%$ formic acid and $3 \%$ hexafluoroacetone in 1:3 mixture of $\mathrm{CD}_{2} \mathrm{Cl}_{2}$ and $\left(\mathrm{CH}_{3}\right)_{2} \mathrm{O}$.

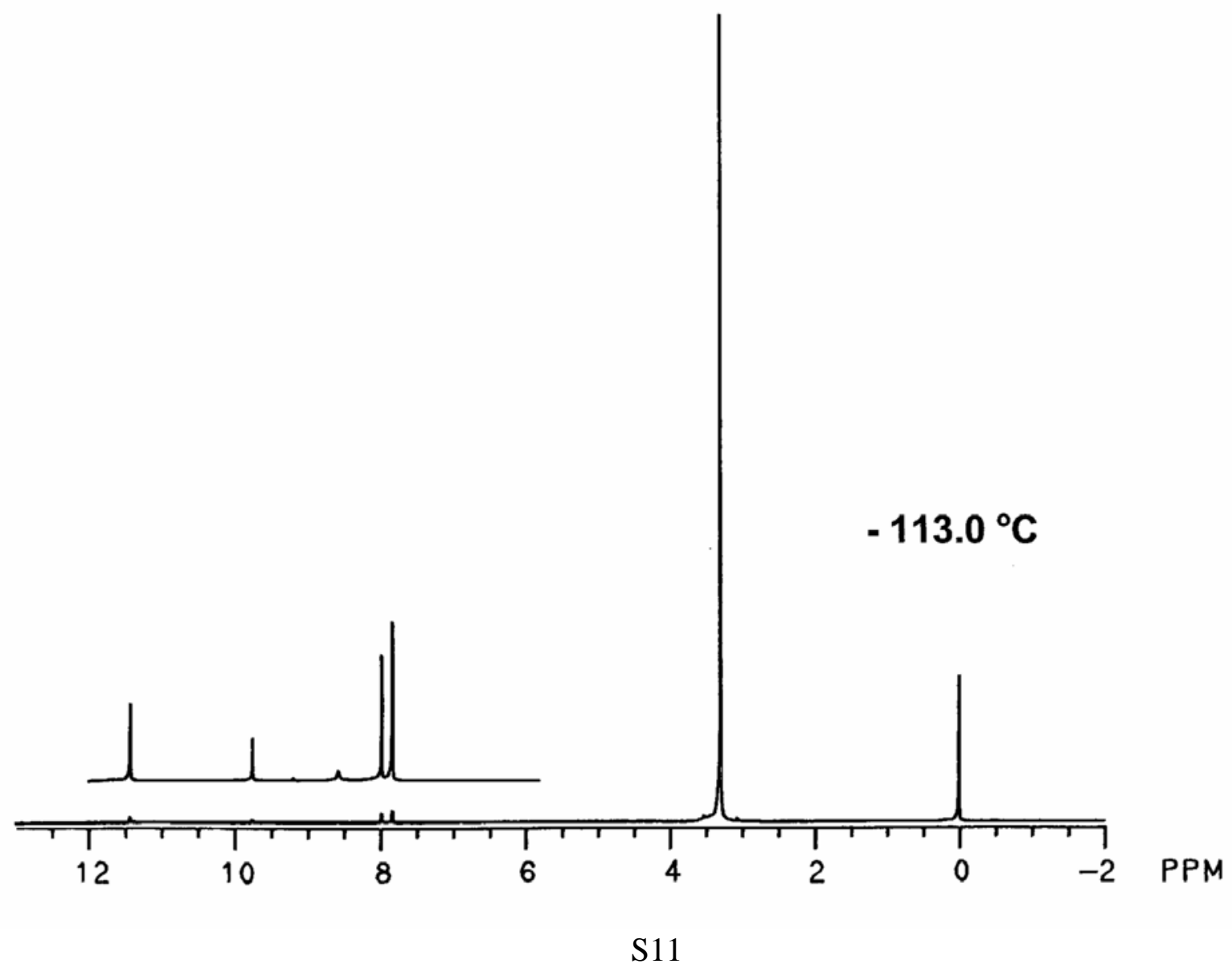


Figure S11. Low - temperature ${ }^{1} \mathrm{H}$ NMR spectra of $2 \%$ formic acid and $3 \%$ hexafluoroacetone in 1:3 mixture of $\mathrm{CD}_{2} \mathrm{Cl}_{2}$ and $\left(\mathrm{CH}_{3}\right)_{2} \mathrm{O}$.

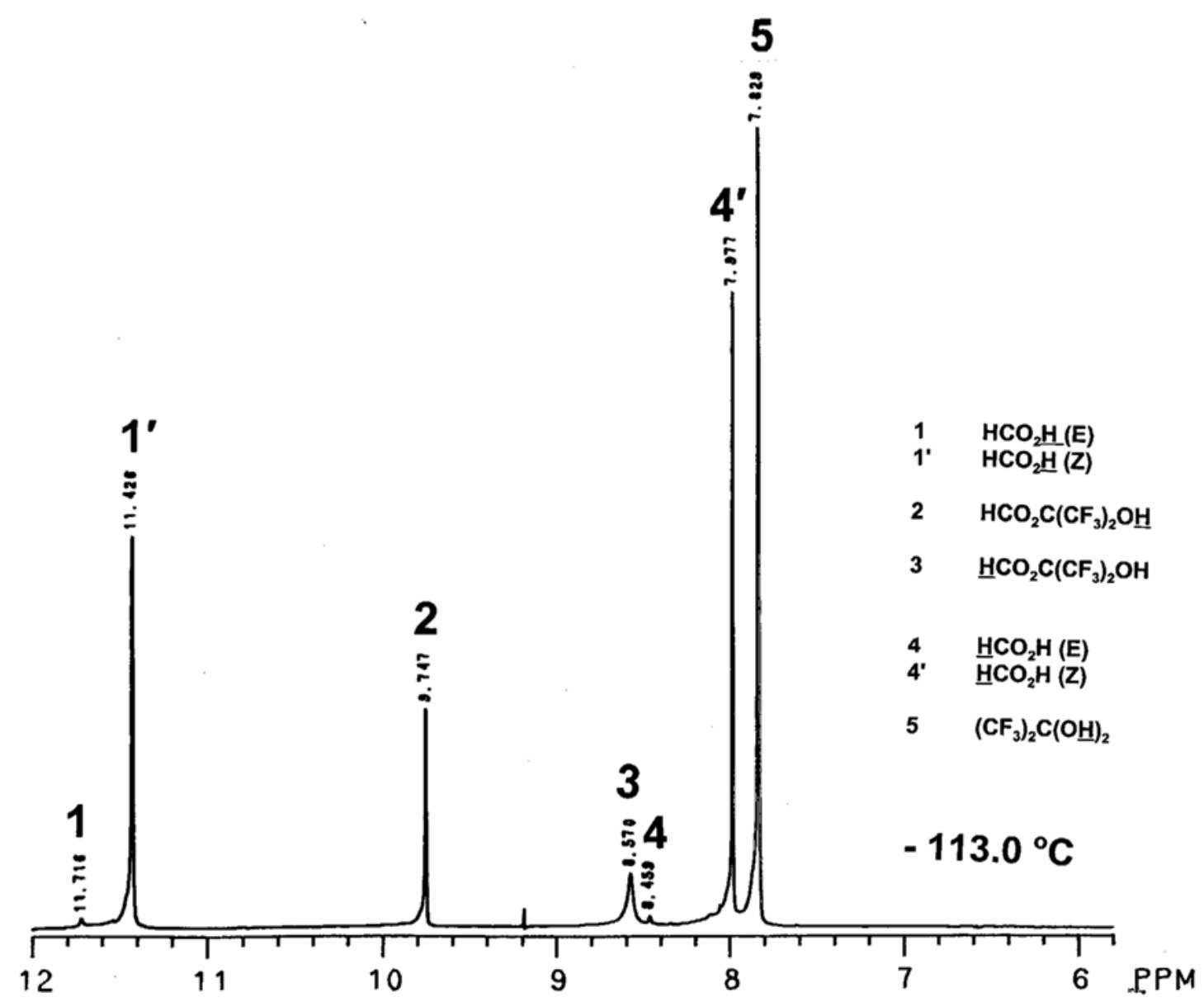


Figure S12. Low - temperature ${ }^{1} \mathrm{H}$ NMR spectra of $2 \%$ formic acid and $3 \%$ hexafluoroacetone in $1: 3$ mixture of $\mathrm{CD}_{2} \mathrm{Cl}_{2}$ and $\left(\mathrm{CH}_{3}\right)_{2} \mathrm{O}$.

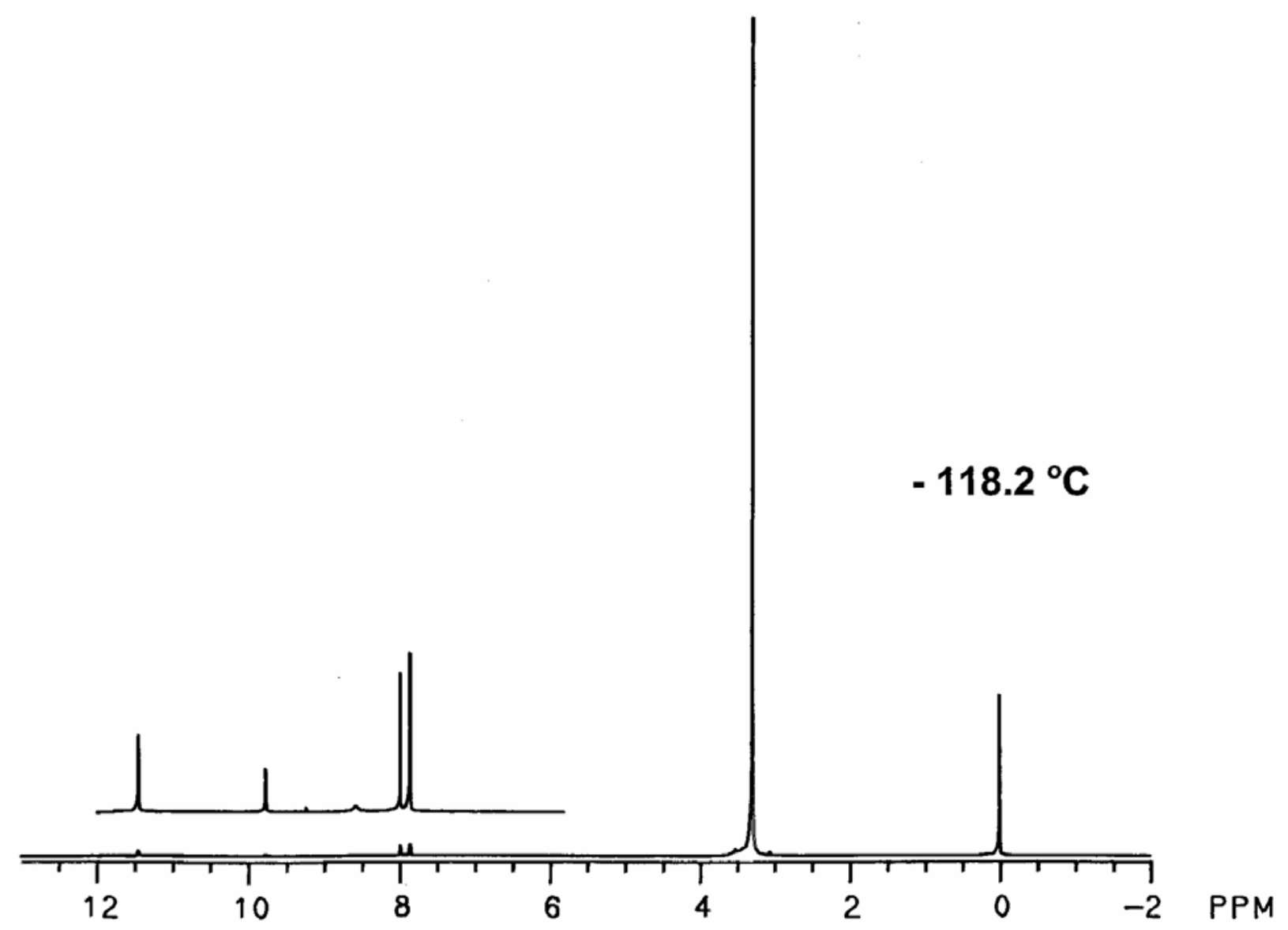


Figure S13. Low - temperature ${ }^{1} \mathrm{H}$ NMR spectra of $2 \%$ formic acid and $3 \%$ hexafluoroacetone in $1: 3$ mixture of $\mathrm{CD}_{2} \mathrm{Cl}_{2}$ and $\left(\mathrm{CH}_{3}\right)_{2} \mathrm{O}$.

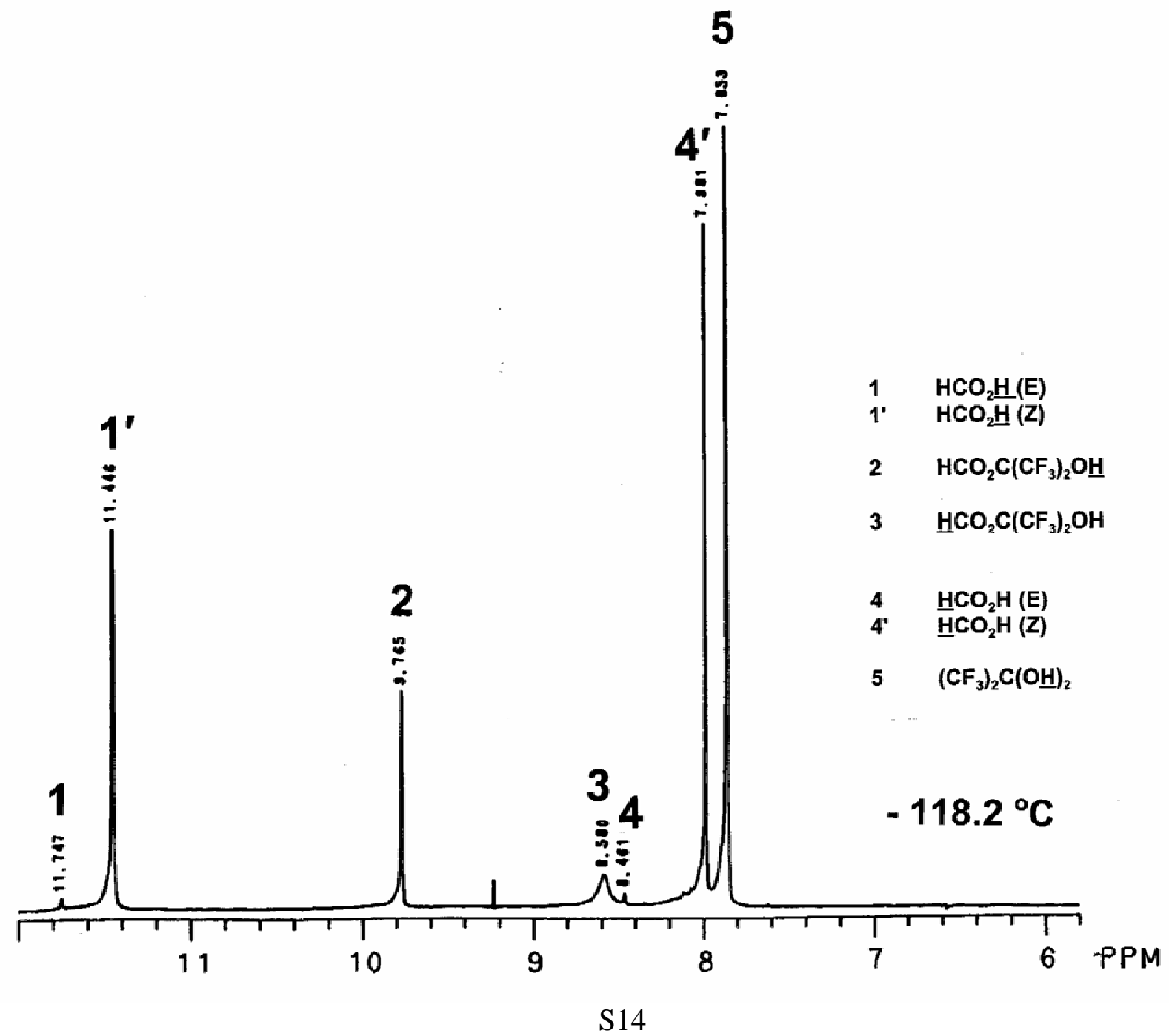


Figure S14. Low - temperature ${ }^{1} \mathrm{H}$ NMR spectra of $2 \%$ formic acid and $3 \%$ hexafluoroacetone in 1:3 mixture of $\mathrm{CD}_{2} \mathrm{Cl}_{2}$ and $\left(\mathrm{CH}_{3}\right)_{2} \mathrm{O}$.

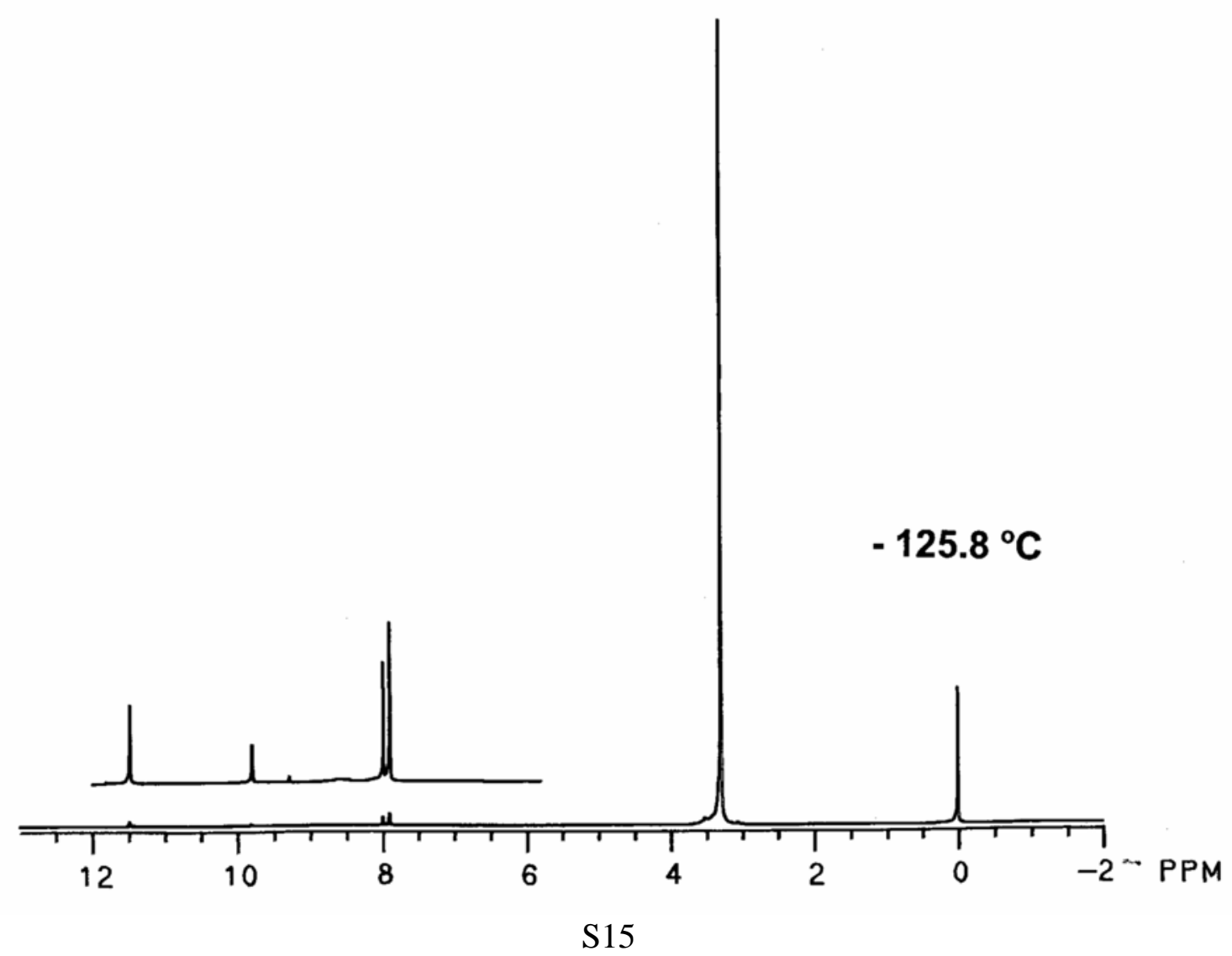


Figure S15. Low - temperature ${ }^{1} \mathrm{H}$ NMR spectra of $2 \%$ formic acid and $3 \%$ hexafluoroacetone in 1:3 mixture of $\mathrm{CD}_{2} \mathrm{Cl}_{2}$ and $\left(\mathrm{CH}_{3}\right)_{2} \mathrm{O}$.

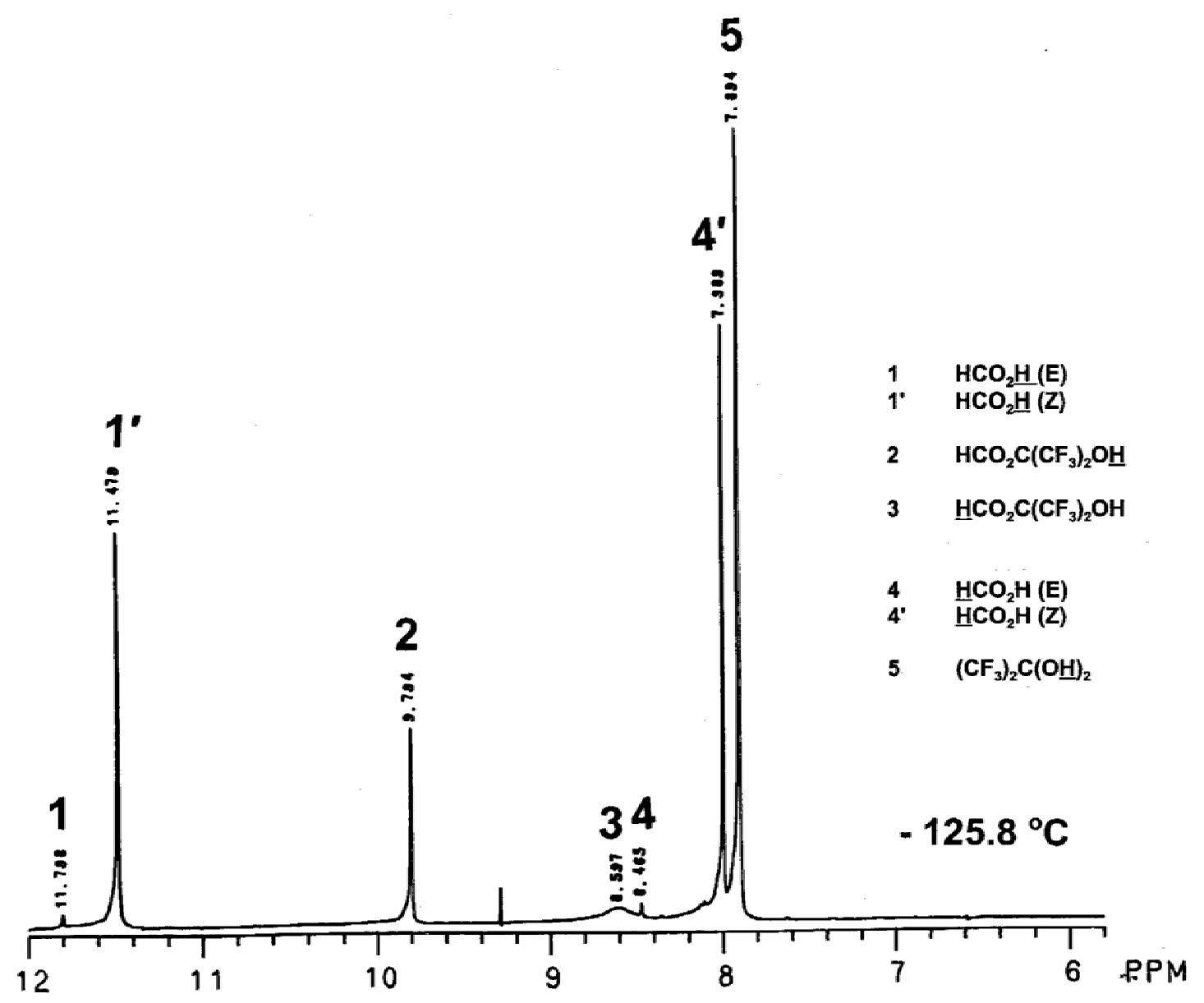


Figure S16. Low - temperature ${ }^{1} \mathrm{H}$ NMR spectra of $2 \%$ formic acid and $3 \%$ hexafluoroacetone in 1:3 mixture of $\mathrm{CD}_{2} \mathrm{Cl}_{2}$ and $\left(\mathrm{CH}_{3}\right)_{2} \mathrm{O}$.




Figure S17. Low - temperature ${ }^{1} \mathrm{H}$ NMR spectra of $2 \%$ formic acid and $3 \%$ hexafluoroacetone in $1: 3$ mixture of $\mathrm{CD}_{2} \mathrm{Cl}_{2}$ and $\left(\mathrm{CH}_{3}\right)_{2} \mathrm{O}$.

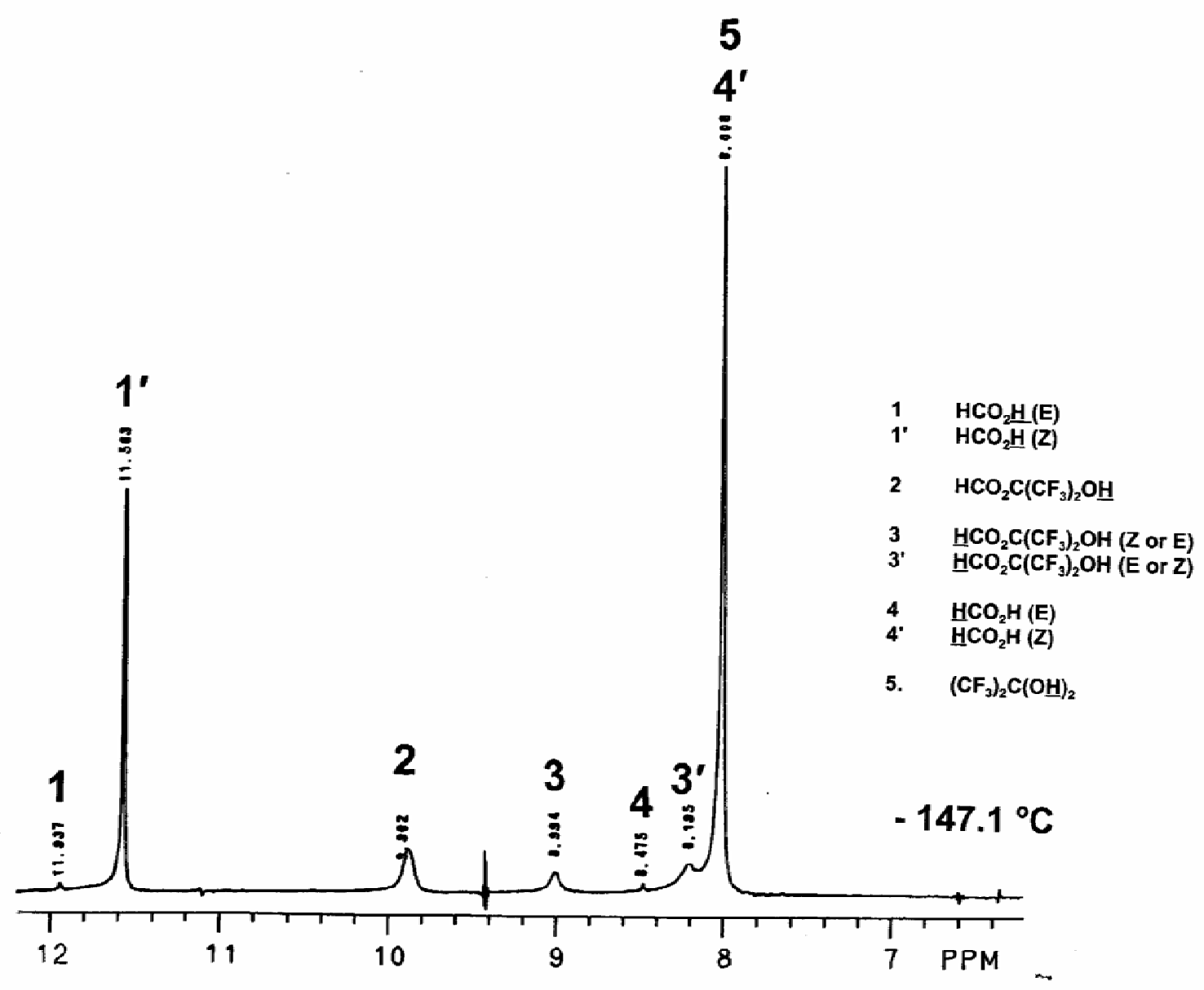


Figure S18. Low - temperature ${ }^{1} \mathrm{H}$ NMR spectra of $2 \%$ formic acid and $3 \%$ hexafluoroacetone in 1:3 mixture of $\mathrm{CD}_{2} \mathrm{Cl}_{2}$ and $\left(\mathrm{CH}_{3}\right)_{2} \mathrm{O}$.

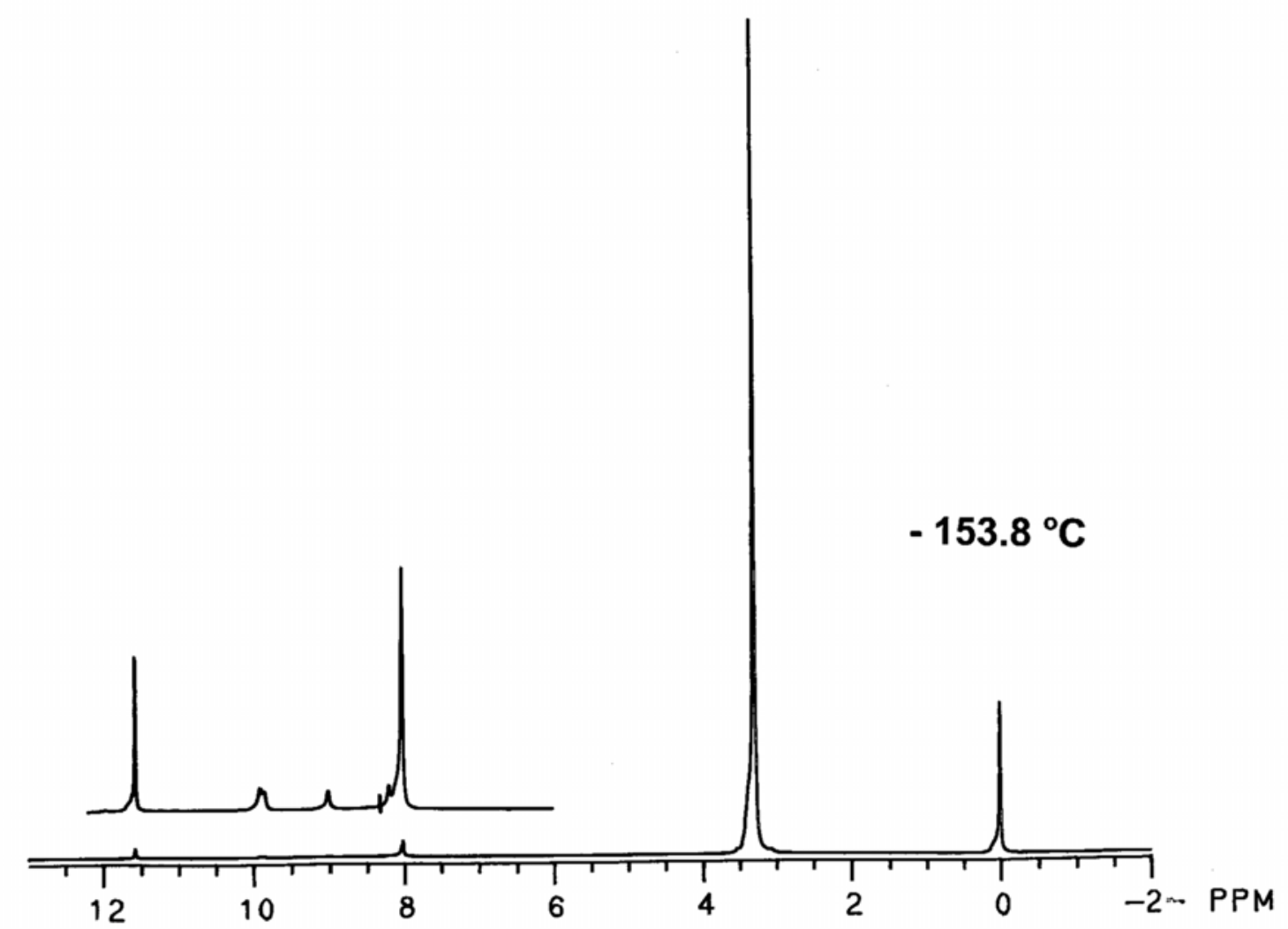


Figure S19. Low - temperature ${ }^{1} \mathrm{H}$ NMR spectra of $2 \%$ formic acid and $3 \%$ hexafluoroacetone in 1:3 mixture of $\mathrm{CD}_{2} \mathrm{Cl}_{2}$ and $\left(\mathrm{CH}_{3}\right)_{2} \mathrm{O}$.

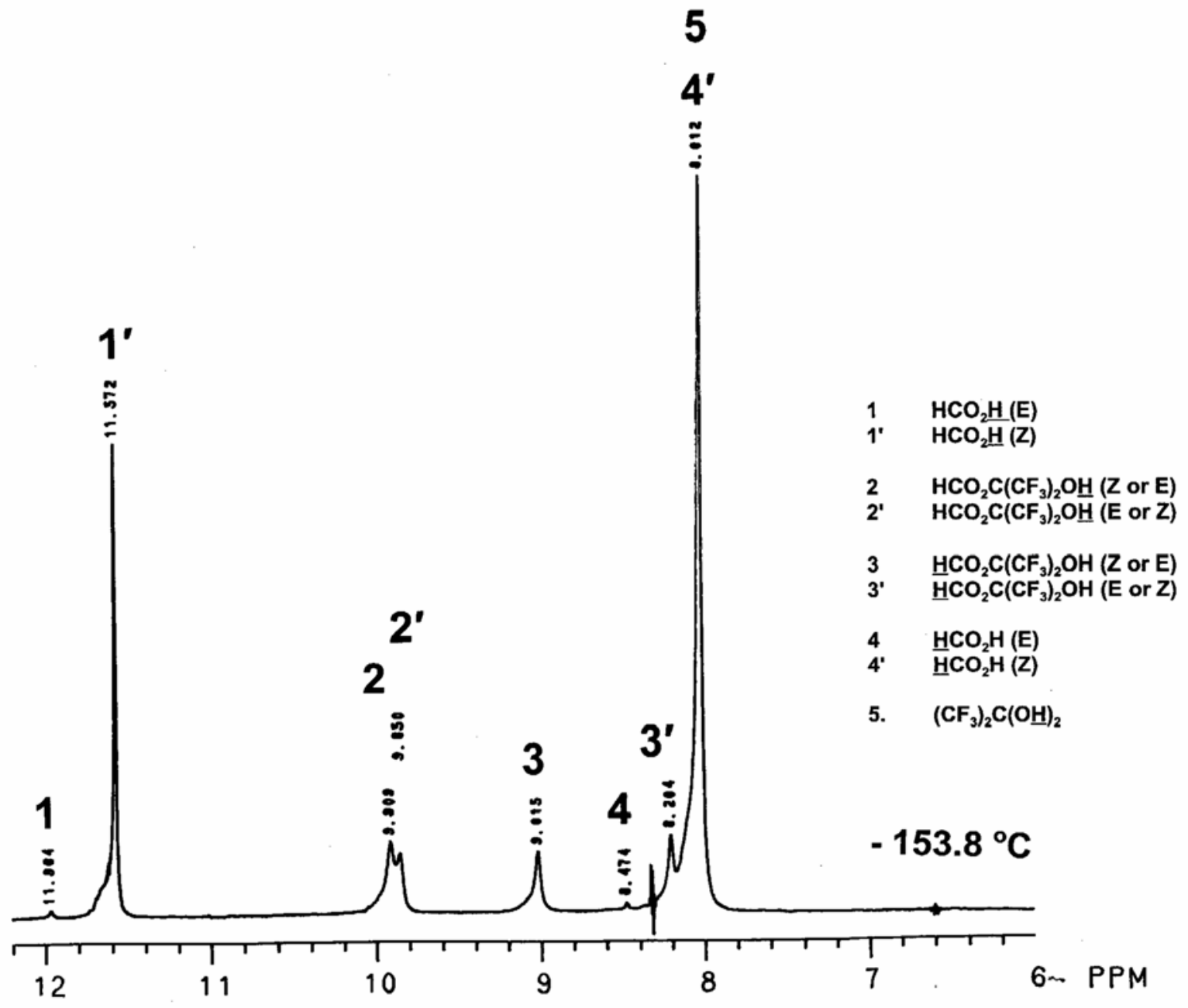


Figure S20. Low - temperature ${ }^{13} \mathrm{C}$ NMR spectra of $2 \%$ formic acid and $3 \%$ hexafluoroacetone in 1:3 mixture of $\mathrm{CD}_{2} \mathrm{Cl}_{2}$ and $\left(\mathrm{CH}_{3}\right)_{2} \mathrm{O}$.

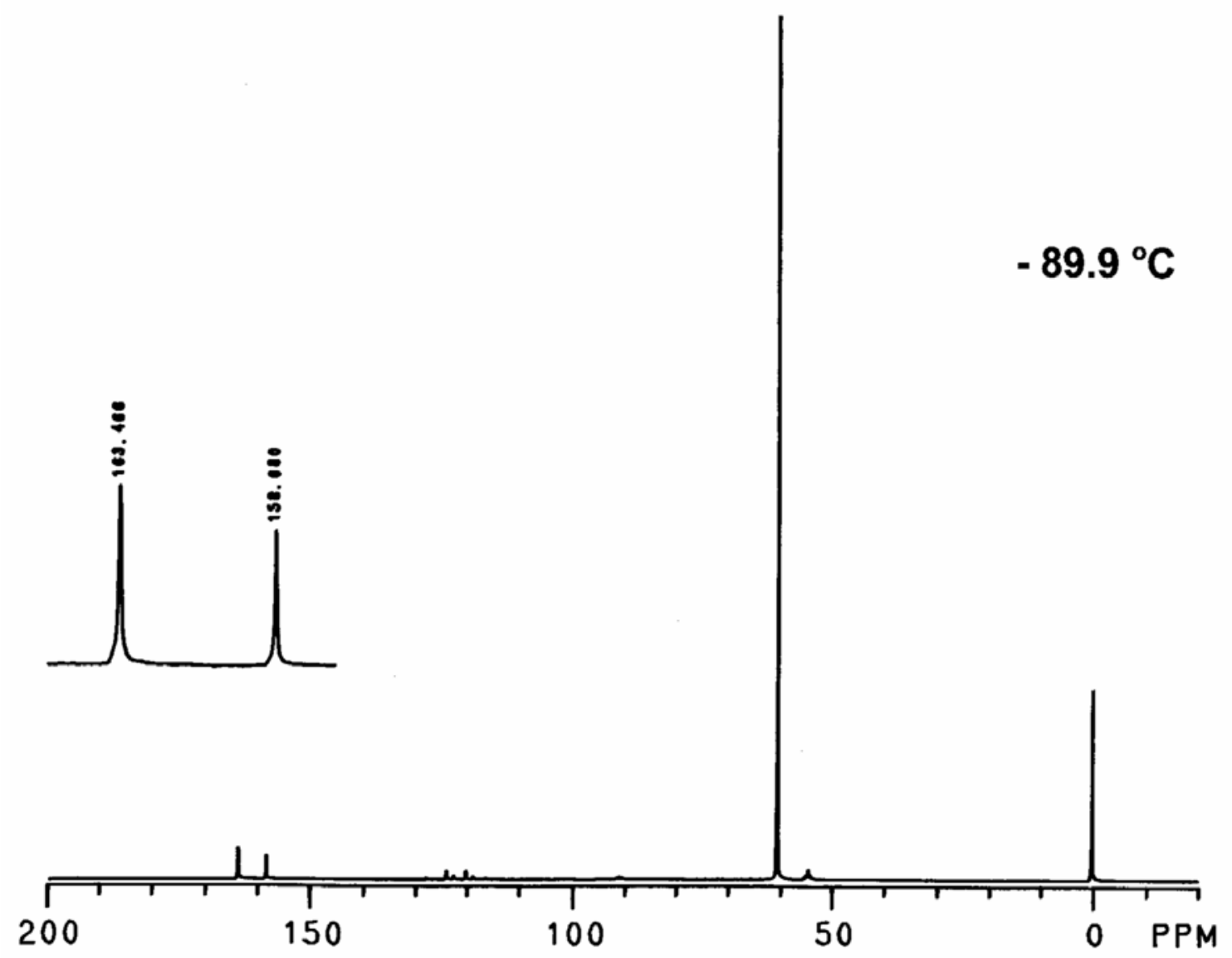


Figure S21. Low - temperature ${ }^{13} \mathrm{C}$ NMR spectra of $2 \%$ formic acid and $3 \%$ hexafluoroacetone in 1:3 mixture of $\mathrm{CD}_{2} \mathrm{Cl}_{2}$ and $\left(\mathrm{CH}_{3}\right)_{2} \mathrm{O}$.




Figure S22. Low - temperature ${ }^{13} \mathrm{C}$ NMR spectra of $2 \%$ formic acid and $3 \%$ hexafluoroacetone in 1:3 mixture of $\mathrm{CD}_{2} \mathrm{Cl}_{2}$ and $\left(\mathrm{CH}_{3}\right)_{2} \mathrm{O}$.

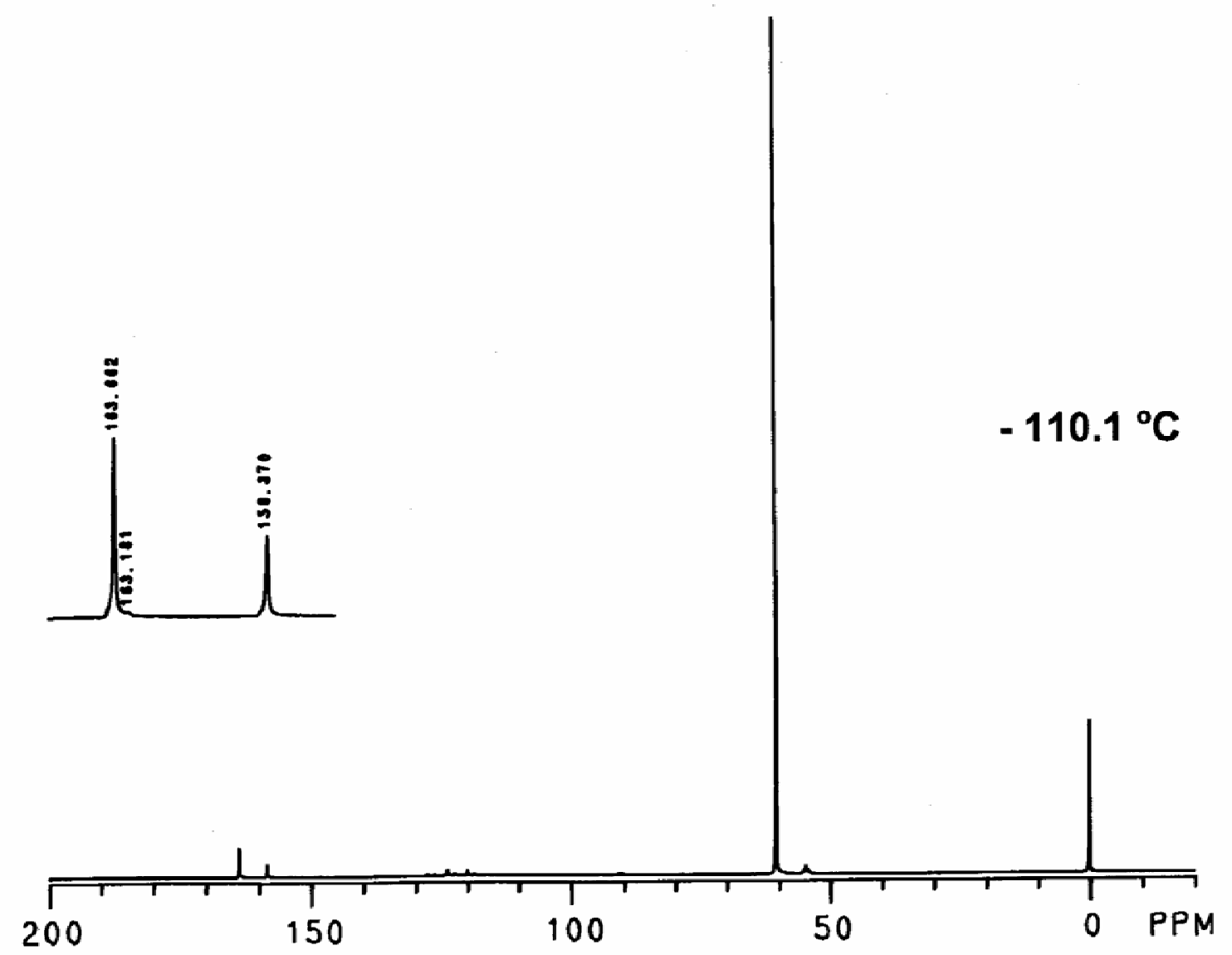


Figure S23. Low - temperature ${ }^{13} \mathrm{C}$ NMR spectra of $2 \%$ formic acid and $3 \%$ hexafluoroacetone in 1:3 mixture of $\mathrm{CD}_{2} \mathrm{Cl}_{2}$ and $\left(\mathrm{CH}_{3}\right)_{2} \mathrm{O}$.

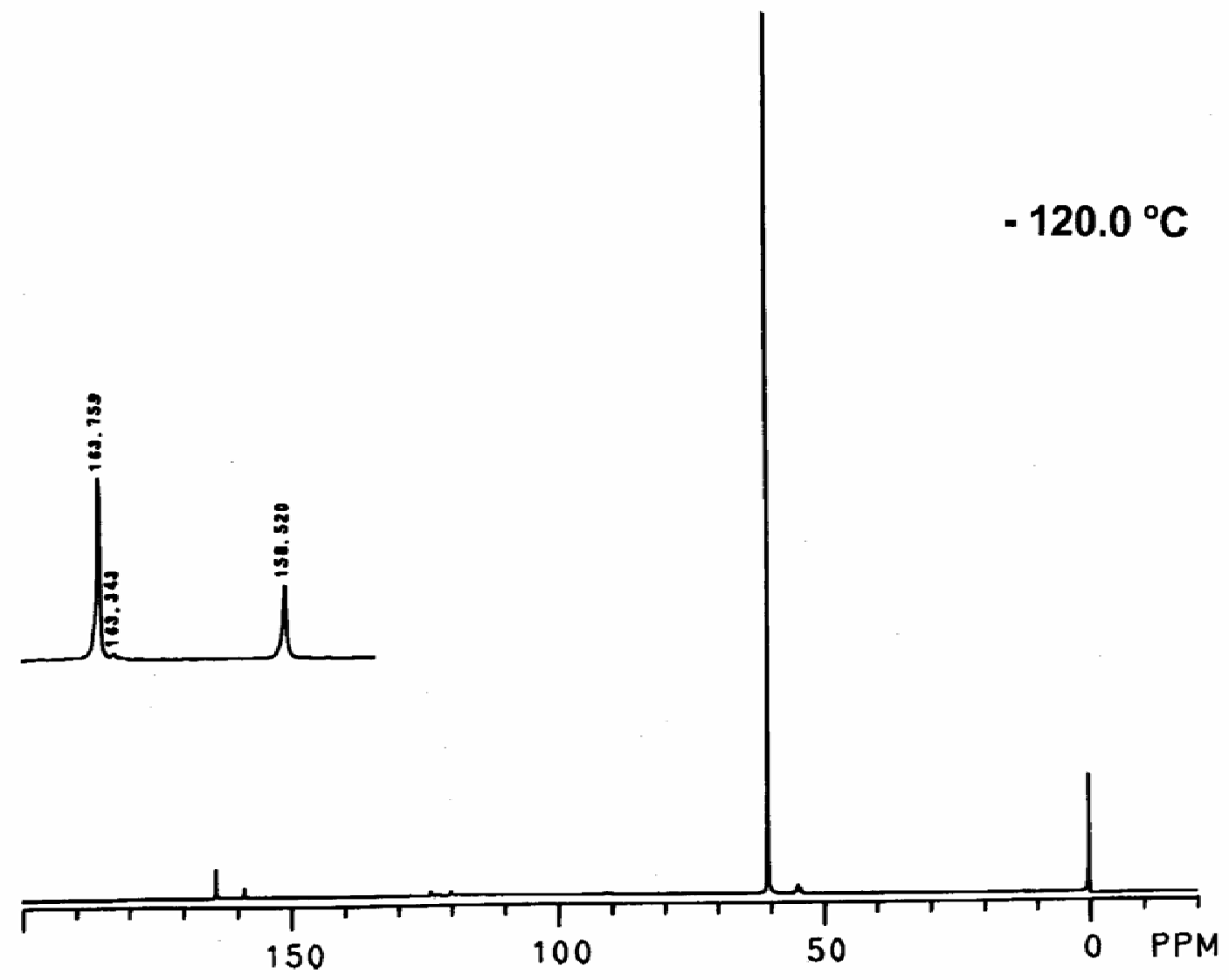


Figure S24. Low - temperature ${ }^{13} \mathrm{C}$ NMR spectra of $2 \%$ formic acid and $3 \%$ hexafluoroacetone in 1:3 mixture of $\mathrm{CD}_{2} \mathrm{Cl}_{2}$ and $\left(\mathrm{CH}_{3}\right)_{2} \mathrm{O}$. Only carbonyl carbon region is shown.

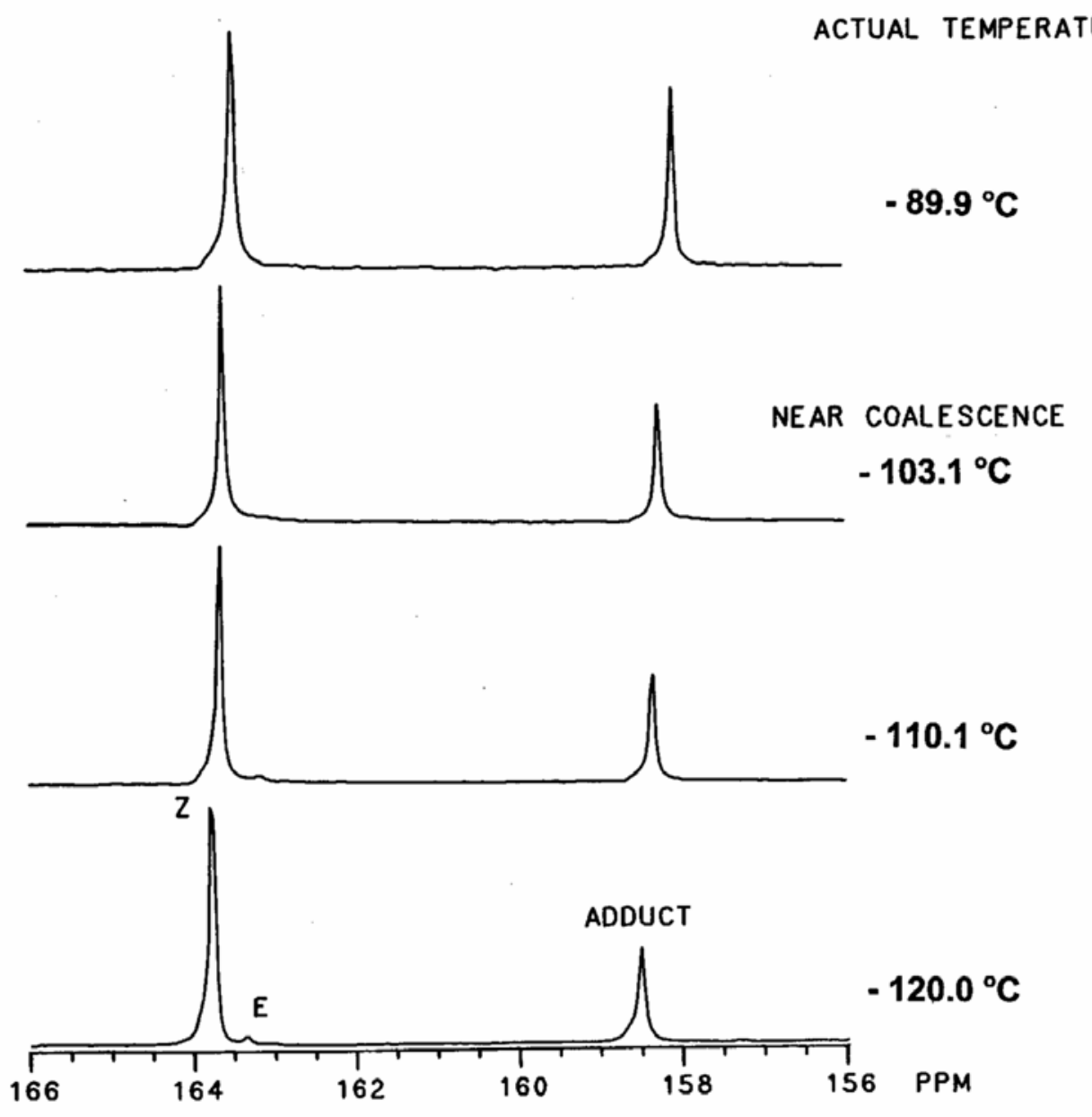

